\title{
Prevalence and factors associated with dyslipidemia after liver transplantation
}

\author{
Hélem de Sena Ribeiro ${ }^{*}$, Lucilene Rezende Anastácio² ${ }^{2}$, Lívia Garcia Ferreira ${ }^{3}$, Érika Barbosa Lagares ${ }^{4}$, Agnaldo Soares \\ Lima ${ }^{5}$, Maria Isabel Toulson Davisson Correia ${ }^{5}$ \\ ${ }^{1}$ Postgraduate Program in Food Science, Faculty of Pharmacy, Federal University of Minas Gerais, Belo Horizonte, MG, Brazil. \\ ${ }^{2}$ Postgraduate Program in Adult Health, Faculty of Medicine, Federal University of Minas Gerais, Belo Horizonte, MG, Brazil. \\ ${ }^{3}$ Postgraduate Program in Sciences applied to Surgery and Ophthalmology, Faculty of Medicine, Federal University of Minas Gerais, Belo Horizonte, MG, Brazil. \\ ${ }^{4}$ Nutritionist, Graduate of the University of Itaúna, Itaúna, MG, Brazil. \\ ${ }^{5}$ Alfa Institute of Gastroenterology, Hospital das Clínicas, Faculty of Medicine, Federal University of Minas Gerais, Belo Horizonte, MG, Brazil.
}

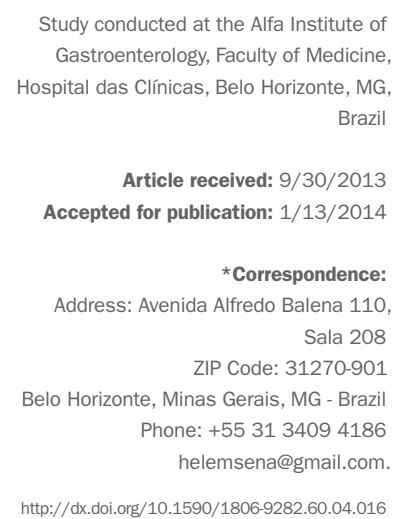

Study conducted at the Alfa Institute of Gastroenterology, Faculty of Medicine, Hospital das Clínicas, Belo Horizonte, MG,

Article received: 9/30/2013 Accepted for publication: $1 / 13 / 2014$

*Correspondence:

Address: Avenida Alfredo Balena 110, Sala 208

ZIP Code: 31270-901

Belo Horizonte, Minas Gerais, MG - Brazil Phone: +553134094186 helemsena@gmail.com.

http://dx.doi.org/10.1590/1806-9282.60.04.016 Conflict of interest: none

\section{SUMmary}

Objective: to determine the prevalence of abnormal total cholesterol (TC), low density lipoprotein (LDL), high density lipoprotein (HDL) and triglycerides in patients undergoing liver transplantation (LTx) and to identify predictors of these disorders.

Methods: cross-sectional study to assess the prevalence of dyslipidemia in patients undergoing LTx. Demographic, socioeconomic, clinical, anthropometric and dietetic data were collected to determine the association with dyslipidemia using univariate and multivariate statistical analysis.

Results: 136 patients were evaluated, $68.1 \%$ of which had at least one type of dyslipidemia. The triglyceride level was high in $32.4 \%$ of cases, with low HDL in $49.3 \%$ of patients and high LDL levels in only $8.8 \%$. High total cholesterol was observed in $16.2 \%$ of the study population and was associated with the recommendation for transplantation due to ethanolic cirrhosis $(\mathrm{OR}=2.7)$ and a greater number of hours slept per night $(\mathrm{OR}=1.5)$.

Conclusion: many patients presented dyslipidemia after transplantation, demonstrating the need for interventions in relation to modifiable factors associated with dyslipidemias that can mitigate or prevent these disorders.

Uniterms: dyslipidemia, lipoprotein, prevalence, liver transplantation.

\section{INTRODUCTION}

The most important risk factors for atherosclerosis include dyslipidemias, which represent an increase or decrease in plasma lipoproteins involved directly and indirectly in the atherothrombotic process. ${ }^{1}$ Many studies have described the high prevalence and incidence of this disorder in patients submitted to liver transplantation. ${ }^{2-6}$ Furthermore, other cardiovascular risk factors, such as hypertension, obesity and diabetes have been commonly reported after liver transplants. ${ }^{3,5,7}$ Therefore, patients submitted to this procedure have an increased risk of developing cardiovascular diseases - which have already been indicated as the third most common cause of death in this population by certain authors. ${ }^{8}$
Changes in the lipid profile of patients submitted to transplants have been related to immunosuppressive drug treatment. Some authors have shown a greater increase in total cholesterol and triglycerides in patients submitted to long term immunosuppressive therapy with cyclosporine. ${ }^{2-4,9}$ Changing immunosuppressive treatment with ciclosporine for tacrolimus has also been related to a reduction in the levels of triglycerides and cholesterol in this population. ${ }^{9}$ There are also authors that attribute changes in the lipid profile to the use of prednisone, regardless of treatment with ciclosporine or tacrolimus. ${ }^{10}$ Immunosuppressive therapy with the use of sirolimus has also been strongly related to hyperlipidemia in pa- 
tients submitted to kidney transplants. ${ }^{11-12}$ However, in patients submitted to liver transplants, this type of immunosuppression does not appear to cause significant alterations in plasma lipoproteins in comparison with other treatments. ${ }^{13}$ unless this medication is associated with cyclosporine. ${ }^{14}$ Although immunosuppressive medication has been widely studied as a possible cause of post-liver transplant dyslipidemias, few other risk factors have been studied. At present, nothing is known about the prevalence of dyslipidemias in the Brazilian population submitted to liver transplantation.

The objective of this study was to determine the prevalence of abnormalities in total cholesterol (TC), low density lipoprotein (LDL), high density lipoprotein (HDL) and triglycerides in patients submitted to liver transplants, as well as identifying predictive factors for these disorders.

\section{Methods}

This was a cross-sectional study evaluating the prevalence of dyslipidemia and associated factors in patients undergoing liver transplantation monitored at the transplant outpatient clinic at the Alfa Institute of Gastroenterology, Hospital das Clínicas, Federal University of Minas Gerais (Belo Horizonte - MG, Brazil). The study included patients who underwent transplantation, aged over 18 years, who had regular follow-ups at the clinic. Pregnant women, patients with ascites and/ or patients with less than one year since transplantation were excluded. The study was approved by the Ethics Committee at the Federal University of Minas Gerais under report $\mathrm{n}^{\circ}$. ETIC 44/08.

Patients were approached and asked about their interest in participating in the study while waiting for their medical consultation at the outpatient clinic. After signing an informed consent form, a questionnaire was applied with respect to demographic, socioeconomic, lifestyle, clinical, anthropometric and dietary data. Subsequently, after a 12 hour fast, patients underwent biochemical exams for measurement of plasma lipoproteins, along with the routine biochemical exams at the clinic. The cutoff points used for classification of dyslipidemias were those proposed by the III Brazilian Guidelines on Dyslipidemia (2001): ${ }^{15}$ borderline $(150-200 \mathrm{mg} / \mathrm{dL})$ and high triglycerides $(\geq 200$ $\mathrm{mg} / \mathrm{dL})$; grouped into increased triglycerides $(\geq 150$ $\mathrm{mg} / \mathrm{dL})$, low HDL $(\mathrm{HDL} \leq 40 \mathrm{mg} / \mathrm{dL}$ for men and $\leq 50$ $\mathrm{mg} / \mathrm{dL}$ for women), borderline $(130-159 \mathrm{mg} / \mathrm{dL})$ and high LDL $\left({ }^{3} 160 \mathrm{mg} / \mathrm{dL}\right)$, which were grouped into increased LDL $(\geq 130 \mathrm{mg} / \mathrm{dL})$, borderline $(200-239 \mathrm{mg} /$ $\mathrm{dL}$ ) and high cholesterol ( $\geq 240 \mathrm{mg} / \mathrm{dL})$, grouped into increased total cholesterol levels $(\geq 200 \mathrm{mg} / \mathrm{dL}$ ). This classification served as the basis for determining the prevalence of dyslipidemia and the investigation into predictors.

The data was collected directly from the medical records and with the aid of the questionnaire elaborated covering the demographic and socioeconomic variables as well as data on lifestyle, clinical and anthropometric details, past medical history and dietary intake. The patients were also questioned about their daily physical activities, which were then transformed into corresponding activity factors. ${ }^{16}$ The daily activities transformed into factors were multiplied by the respective time spent and the results were added and divided over 24 hours. This value was categorized according to the daily level of physical activity carried out (<1.3: sedentary; $1.3-1.5$ : slightly active; $1.5-1.8$ : active; > 1.9: very active). ${ }^{17}$

The clinical data included indication for transplantation, time of use and accumulated dose of corticoids after transplantation, use of tacrolimus and cyclosporine, glucose levels, systolic and diastolic blood pressure, hypertension prior to transplantation and at the time of the interview, diabetes mellitus before transplantation and excess weight and obesity prior to liver disease (using the habitual weight informed by the patient during the interview), family history of hypertension, diabetes mellitus and excess weight.

The anthropometric data was constituted by weight, height, Body Mass Index (BMI), waist circumference (WC), hip circumference (HC) and the waist to hip ratio (WHR). According to the BMI (weight $(\mathrm{kg}) /$ height $\left(\mathrm{m}^{2}\right)$ the patients were classified as being overweight $\left(\mathrm{BMI} \geq 25 \mathrm{~kg} / \mathrm{m}^{2}\right)$ or obese $\left(\mathrm{BMI} \geq 30 \mathrm{~kg} / \mathrm{m}^{2}\right) .{ }^{18}$ The waist circumference measurement (measured two fingers above the navel) was considered as indicative of abdominal obesity according to the definitions of the World Health Organization $(\geq 88 \mathrm{~cm}$ for women and $\geq$ $102 \mathrm{~cm}$ for men $)^{18}$ and by the International Diabetes Federation (IDF) $\left(\geq 80 \mathrm{~cm}\right.$ and $90 \mathrm{~cm}$, respectively). ${ }^{19}$

The dietetic data was obtained using habitual dietary history method. Food intake was evaluated in terms of calories, carbohydrates, proteins, fats (total, saturated, monounsaturated, polyunsaturated fats and 
cholesterol), total fiber, vitamin A, C, D, E, thiamine, riboflavin, niacin, pantothenic acid, vitamin $B_{6}$, folic acid, vitamin $B_{12}$, calcium, iron, magnesium, sodium, potassium and zinc with the aid of Microsoft Excel (Microsoft Corp, Redmond, WA) and the Food Composition Table: Support for Nutritional Decision. ${ }^{20}$ The household measurements of food reported in the habitual dietary history were converted into grams with the help of the Food Intake Evaluation Table in Household Measures. ${ }^{21}$

The statistical analyses were conducted using the program Statistical Package for the Social Sciences (SPSS) for Windows (version 17.0), adopting an equal to $5 \%$ for statistical significance. The variables were presented in the form of means and standard deviations. However, variables with a non-normal distribution were presented in the form of median, minimum and maximum (Kolmogorov-Smirnov test). Factors associated with the presence of dyslipidemia were tested through univariate and multivariate analyses. The statistical tests used in the univariate analysis were the Chi-squared test, Fisher's exact test, Student's t-test and Mann-Whitney $\mathrm{U}$ test. Variables with $\mathrm{p}<0.2$ in the univariate analysis were included in the multiple logistic regression model. The model was then adjusted according to the backward stepwise method. The Hosmer-Lemeshow test was used to check the adjustment of the model ( $p>0.05)$. A multiple linear regression test was also used to identify factors associated with dyslipidemia.

\section{Results}

136 patients were evaluated with an average age of 52.2 \pm 13 years, being $61 \%(n=83)$ male. The average time since transplantation was approximately $4 \pm 3$ years. The general characteristics of the patients are described in Table 1.

TABLE 1 Demographic, socioeconomic, lifestyle and clinical data of the patients submitted to liver transplantation, Belo Horizonte-MG, 2013

\begin{tabular}{|c|c|c|c|c|c|}
\hline Categorical variables & $\%$ & $\mathbf{N}$ & Numerical variables & $\begin{array}{l}\text { Mean / } \\
\text { Median }\end{array}$ & $\begin{array}{l} \pm \text { Standard } \\
\text { deviation / } \\
\text { Minimum- } \\
\text { maximum }\end{array}$ \\
\hline Marital status - married & 30 & 42 & Per capita income (BR\$) & 499 & $83-6,000$ \\
\hline Unemployed/retired/homemaker & 69.1 & 94 & Hours of sleep (per day) & 7.7 & 1.4 \\
\hline Smokers & 11.4 & 15 & Physical activity factor (MET/24) & 1.3 & 0.2 \\
\hline Former smokers & 39.8 & 47 & Glucose (mg/dL) & 96 & $61-346$ \\
\hline Use of tacrolimus & 89 & 121 & Total cholesterol (mg/dL) & 163.9 & 43.5 \\
\hline Use of cyclosporine & 11 & 15 & $\mathrm{LDL}(\mathrm{mg} / \mathrm{dL})$ & 88.8 & 34.3 \\
\hline Hypertension before transplantation & 19.3 & 26 & $\mathrm{HDL}(\mathrm{mg} / \mathrm{dL})$ & 44 & $18-162$ \\
\hline Current hypertension & 41.2 & 56 & Triglycerides (mg/dL) & 124 & $28-659$ \\
\hline Diabetes mellitus before transplantation & 5.9 & 8 & Systolic blood pressure (mmHg) & 120 & $90-180$ \\
\hline Current diabetes mellitus & 21.3 & 29 & Diastolic blood pressure $(\mathrm{mmHg})$ & 80 & $50-110$ \\
\hline Indicated for transplantation & & & Time using prednisone (months) & 4 & $1.5-140$ \\
\hline VHC cirrhosis & 30.9 & 42 & Accumulated prednisone dose (g) & 2.5 & $0.5-39.4$ \\
\hline Ethanolic cirrhosis & 30.9 & 42 & BMI before liver disease & 25.4 & 4.7 \\
\hline Autoimmune hepatitis & 12.5 & 17 & Current BMI & 26.5 & 4.7 \\
\hline Cryptogenic cirrhosis & 11 & 15 & Waist circumference & 95 & 14.4 \\
\hline Cirrhosis and hepatocellular carcinoma & 8.8 & 12 & Hip circumference & 102.3 & 10.4 \\
\hline Primary biliary cirrhosis & 5 & 5 & Waist-hip ratio & 0.93 & 0.08 \\
\hline Secondary biliary cirrhosis & 3.7 & 2 & & & \\
\hline
\end{tabular}


A family history of hypertension, diabetes mellitus and excess weight was found in $73.7 \%(\mathrm{n}=98), 48.5 \%(\mathrm{n}=65)$ and $59 \%(n=79)$ of the patients assessed, respectively. A personal history of being overweight prior to liver disease was observed in $46.3 \%(n=63)$ of the patients and obesity in $16.2 \%(\mathrm{n}=22)$. At the time of evaluation, the prevalence of excess weight was $59.6 \%(\mathrm{n}=81)$ and obesity $20.6 \%(n=28)$. The quantification of dietetic intake of the patients evaluated is described in Table 2.

The presence of at least one type of dyslipidemia was observed in $68.1 \%(\mathrm{n}=93)$ of the patients sub- mitted to liver transplantation. The most frequent type of dyslipidemia was low HDL $(49.3 \%$; $n=67)$ and the least frequent was increased LDL $(8.8 \% ; \mathrm{n}=$ $12)$, with $5.9 \%(\mathrm{n}=8)$ borderline and $2.9 \%(\mathrm{n}=4)$ high levels. Total cholesterol was found to be increased in $16.2 \%(\mathrm{n}=22)$ of the patients, with $11 \%(\mathrm{n}=15)$ borderline and $5.2 \%(\mathrm{n}=7)$ high levels. The triglyceride levels were increased in $32.4 \%(\mathrm{n}=44)$, with $15.4 \%(n=21)$ showing borderline and $16.9 \%(n=23)$ high levels. The predictive factors of these disorders are contained in Table 3 .

TABLE 2 Dietetic consumption of patients submitted to liver transplantation, Belo Horizonte-MG, 2013

\begin{tabular}{|c|c|c|c|c|c|c|c|}
\hline Nutrient & $\begin{array}{l}\text { Median } \\
\text { intake }\end{array}$ & $\begin{array}{l}\text { Minimum } \\
\text { intake }\end{array}$ & $\begin{array}{l}\text { Maximum } \\
\text { intake }\end{array}$ & Nutrient & $\begin{array}{l}\text { Median } \\
\text { intake }\end{array}$ & $\begin{array}{l}\text { Minimum } \\
\text { intake }\end{array}$ & $\begin{array}{l}\text { Maximum } \\
\text { intake }\end{array}$ \\
\hline Kilocalories (kcal) & $1,933.4$ & 476.8 & $3,998.1$ & Vitamin B12 (mcg) & 3.8 & 0 & 19.3 \\
\hline Carbohydrates (g) & 229.3 & 65.8 & 519.4 & Folic acid (mcg) & 179.7 & 24.5 & 536.6 \\
\hline Proteins (g) & 70 & 14.8 & 187.4 & Calcium (mg) & 536.5 & 140.2 & 1577 \\
\hline Lipids (g) & 61.9 & 12.4 & 552 & Iron (mg) & 13.1 & 1.4 & 52.9 \\
\hline Polyunsaturated lipids (g) & 18 & 1.7 & 51.5 & Magnesium (mg) & 210.7 & 62.7 & 907.3 \\
\hline Monounsaturated lipids (g) & 15.6 & 2.3 & 59.8 & Potassium (mg) & $2,287.9$ & 646.9 & $9,411.4$ \\
\hline Saturated lipids (g) & 18.7 & 3 & 63 & Sodium (mg) & $2,201.6$ & 287.9 & $5,425.8$ \\
\hline Carbohydrates \% & 51.7 & 32.7 & 78.3 & Zinc (mg) & 9.2 & 1 & 33 \\
\hline Proteins \% & 15.8 & 7.3 & 44.4 & Per group & & & \\
\hline Lipids \% & 32.1 & 9.5 & 52 & Breads, cereals, tubers ( $\mathrm{g}$ ) & 390 & 89 & 1,680 \\
\hline Polyunsaturated lipids \% & 8.9 & 3.2 & 17.2 & Wholegrain cereals (g) & 0 & 0 & 190 \\
\hline Monounsaturated lipids \% & 8.3 & 3 & 17 & Greenery (g) & 110 & 0 & 521 \\
\hline Saturated lipids \% & 9.4 & 2 & 22.2 & Fruits (g) & 123.4 & 0 & 717 \\
\hline Cholesterol (mg) & 175.4 & 0 & 750 & Vegetables (g) & 140 & 0 & 600 \\
\hline Total fibers (g) & 16.6 & 2 & 72 & Meat (g) & 127 & 0 & 500 \\
\hline Vitamin A (RE) & 890.6 & 57.9 & 4,590 & Sugar-sweetened beverages ( $\mathrm{g}$ ) & 200 & 0 & 2,000 \\
\hline Vitamin C (mg) & 72.5 & 4.1 & 740 & Sweets $(\mathrm{g})$ & 0 & 0 & 500 \\
\hline Vitamin D (mcg) & 1.8 & 0 & 18.7 & Fats (g) & 11 & 0 & 100 \\
\hline Vitamin E (mg) & 17.4 & 2 & 17 & Dairy & & & \\
\hline Vitamin B1 (mg) & 1.5 & 0.2 & 3.3 & Milk (mL) & 150 & 0 & 720 \\
\hline Vitamin B2 (mg) & 1.3 & 0.4 & 3.8 & Whole milk $(\mathrm{mL})$ & 37.5 & 0 & 720 \\
\hline Niacin (mg) & 17.2 & 2.8 & 272.4 & Skim milk (mL) & 0 & 0 & 480 \\
\hline Vitamin B5 (mg) & 3.3 & 0.8 & 9.1 & Yogurt $(\mathrm{mL})$ & 0 & 0 & 150 \\
\hline Vitamin B6 (mg) & 1.5 & 0.3 & 4.9 & Cheese (g) & 0 & 0 & 92 \\
\hline
\end{tabular}


TABLE 3 Independent risk factors associated with dyslipidemias after liver transplantation evaluated using multiple logistic regression, Belo Horizonte-MG, 2013

\begin{tabular}{|c|c|c|c|}
\hline Associated independent factors & OR & $\mathrm{Cl}$ & p Value \\
\hline \multicolumn{4}{|l|}{ High TG } \\
\hline Older age (years) & 1.07 & $1.03-1.01$ & 0.01 \\
\hline Indicated due to cryptogenic cirrhosis & 1.03 & $1.00-1.06$ & 0.05 \\
\hline Higher consumption of whole milk (mL) & 1.00 & $1.00-1.004$ & 0.05 \\
\hline Hosmer-Lemeshow test & & & 0.98 \\
\hline \multicolumn{4}{|l|}{ Low HDL } \\
\hline Waist circumference $>88 / 102 \mathrm{~cm}$ & 3.22 & $1.47-7.05$ & $<0,01$ \\
\hline Triglycerides $\geq 150 \mathrm{mg} / \mathrm{dL}$ & 1.005 & $0.99-1.01$ & 0.08 \\
\hline Lower vegetable intake (g) & 1.01 & $1.001-1.002$ & 0.01 \\
\hline Hosmer-Lemeshow test & & & 0.77 \\
\hline \multicolumn{4}{|l|}{ High LDL } \\
\hline Higher folic acid intake (mg) & 1.02 & $1.007-1.035$ & $<0,01$ \\
\hline Lower potassium intake (mg) & 1.01 & $1.01-1.001$ & 0.01 \\
\hline Higher fruit intake (g) & 1.01 & $1.001-1.011$ & 0.02 \\
\hline Higher meat intake (g) & 1.01 & $1.002-1.023$ & 0.02 \\
\hline Unemployed/retired/homemaker & 16.60 & $1.26-219.68$ & 0.03 \\
\hline Presence of diabetes prior to transplantation & 10.49 & $1.16-95.19$ & 0.04 \\
\hline Hosmer-Lemeshow test & & & 0.77 \\
\hline \multicolumn{4}{|l|}{ High TC } \\
\hline More hours of sleep per night & 1.45 & $1.02-2.07$ & 0.04 \\
\hline Indicated due to ethanolic cirrhosis & 2.66 & $0.99-7.11$ & 0.05 \\
\hline Hosmer-Lemeshow test & & & 0.41 \\
\hline
\end{tabular}

\section{Discussion}

This study confirms that dyslipidemias are frequently seen in the population undergoing liver transplantation, given that $68.1 \%$ of the patients evaluated presented at least one of these disorders. This is a similar result to those already described in the international literature for this specific population, which indicated the prevalence of dyslipidemias between $66 \%$ and $85 \%$ of individuals., $22-24$ However, the difficulty in comparing the prevalence should be reiterated, due to the different cutoff points used in different studies as well as the specific time in which the patient was evaluated after the transplant.

In Brazil, few studies have been conducted to determine the prevalence of dyslipidemias in the general population and no population undergoing liver transplantation. The majority of these studies was conducted with restricted and limited groups and did not describe the entire lipid profile. We noted that the dyslipidemia prevalence values found in this study are generally higher than those described in the general population. The prevalence of increased triglycerides has already been indicated at 17.1 to $29.5 \%^{2525-26,26}$ in the general Brazilian po- pulation, and reduced HDL from 10.7 to $18.3 \% .^{25,26}$ On the other hand, the prevalence of increased total cholesterol and LDL are described in a greater percentage of the Brazilian population than that found in this study, from 21.6 to $40 \%{ }^{27}$ and 3.5 to $31.1 \%,{ }^{25-26}$ respectively.

The prevalence of high triglycerides has already been reported as between 45 and $49.7 \%$ in the population submitted to liver transplantation, ${ }^{2,4-5}$ which is higher than that found in this study (32.4\%). Older age, an indication for cryptogenic cirrhosis and higher intake of whole milk were independently associated with the presence of increased triglycerides. In 2007, Alexander and colleagues showed an increase in triglyceride levels with increasing age, although the increase was found to be nonlinear, with some decline from 50 years of age. The dyslipidemia characterized by high triglyceride levels and often accompanied by low HDL levels is commonly found in patients with non-alcoholic fatty liver disease. ${ }^{28} \mathrm{~A}$ higher intake of whole milk was also associated with high triglycerides, which can probably be associated with the higher intake of total and saturated fats, which directly interfere with 
lipid metabolism. ${ }^{1}$ However, it should be emphasized that neither the total fat intake or saturated fat intake in the habitual dietary history were associated with higher levels of triglycerides.

The prevalence of low HDL was $49.3 \%$, in agreement with the values found in the literature, in which approximately half the population undergoing liver transplantation has low levels of this lipoprotein. ${ }^{3,5,23}$ Predictive factors for this finding in the study were abdominal obesity, high triglycerides, and low intake of vegetables. The inverse association between the consumption of vegetables, especially greens, and dyslipidemia has been well reported in the literature. This is attributed to the increased fiber content, antioxidant phytochemicals as well as the low glycemic index of such foods. ${ }^{30-31}$ High waist circumference is also indicated in the general population as a predictor of low HDL levels and consequent increased cardiovascular risk. ${ }^{32}$ Abdominal obesity is detrimental because the intra-abdominal fat is more likely to be subject to lipolysis, expressing an increased number of glucocorticoid receptors and more sensitive to catecholamines. ${ }^{33}$ Lipolysis generates more free fatty acids in the bloodstream, which will be released in large quantities into the hepatic portal circulation, promoting resistance in the tissue to the action of insulin, both in the liver and peripheral tissues. ${ }^{34}$ Insulin resistance will lead to hyperinsulinemia, which increases the flow of fatty acids in the liver, contributing to increased hepatic fat. Furthermore, increased synthesis of very low density lipoprotein (VLDL) increases triglyceride in the blood stream. ${ }^{35}$ Increased circulating triglycerides modify the composition and metabolism of HDL, reducing the cholesterol content of increasing triglycerides, which promotes increased clearance in the circulation. ${ }^{36}$

The prevalence of high LDL is rarely reported in the literature, both in the general population and those undergoing liver transplantation. In this study, increased potassium intake was a protective factor for high LDL. This micronutrient is present in vegetables (fruits, greens and legumes), which emphasizes the importance of increasing the intake of foods from this group. ${ }^{37}$ On the other hand, a higher intake of folic acid and fruits remained as a predictive factor for increased LDL values in the model. Although a higher intake of fruits and folic acid may protect individuals from increased plasma LDL and VLDL levels, ${ }^{31}$ in this study the contrary association observed may be due to changes in the lifestyles of patients with high LDL values.

Furthermore, the absence of paid professional activity was associated with high LDL values. Patients with liver failure often stop working or retire while they are seriously ill or on waiting lists for liver transplantation. However, even after transplantation, most of them usually do not return to work ${ }^{38}$ and/or remain sedentary, as low levels of physical activity are the norm among these individuals. ${ }^{39}$ It is known that moderate and constant physical exercise leads to decreased plasma concentration of LDL, by improving the control of oxidative stress in an acute manner, in addition to being inversely related to the atherogenic process. ${ }^{40}$ Despite this finding, no relationship between the level of physical activity and dyslipidemia was found in this study. This was probably due to the limitations of calculating the level of daily physical activity. Increased LDL levels were also associated with the presence of diabetes mellitus prior to transplantation. This can be attributed to the effects of hyperinsulinemia, since insulin resistance promotes an increased flow of free fatty acid and increases the number of VLDL particles and triglyceride plasma levels, promoting decreased levels of HDL and an increased concentration of LDL. ${ }^{41-42}$

The prevalence of increased cholesterol reported in the literature varies from 19 to $26 \%^{2,22,24}$, higher levels than those found in our study (16.2\%). A lower number of hours slept per night, especially less than seven, have been associated with high levels of total cholesterol and lower HDL. ${ }^{43}$ Sleep deprivation can increase the risk of hypercholesterolemia due to several factors. These include reports of increased appetite and increased dietary intake of saturated fats, decreased motivation to engage in regular physical activity, as well as promoting stress and increased levels of catecholamines. ${ }^{43}$ The identification of this variable as a predictor of increased total cholesterol levels in liver graft receptors is unprecedented. No work on dyslipidemia in patients undergoing liver transplantation to date has studied the relationship between the number of hours of sleep and this condition..$^{2-4,6}$ There are studies in the literature relating a higher number of hours of sleep per night and higher total cholesterol levels, but both increased (> 8 hours/day) and decreased ( $<7$ hours/day) sleep duration represent an increased risk of cardiovascular disease, diabetes and emergence of symptoms related to these conditions. ${ }^{44}$ The primary explanation to the deleterious effects of a greater number of hours of sleep is related to the fact that people who sleep more have lower levels of daily physical activity and consequently reduced energy expenditure. ${ }^{45}$

The indication for transplantation due to ethanolic cirrhosis was also a predictor of increased total cholesterol. Although cirrhotic patients must permanently abs- 
tain from alcohol to go on the transplant waiting list, it is likely that the former drinker will keep their old habits, generally associated with the intake of alcohol, as well as higher intake of fatty meats. A high intake of protein, total fats, saturated fats and cholesterol by light drinkers compared to nondrinkers has already been described in the literature. ${ }^{46}$ In this study, former drinkers had a significantly increased intake of calories, protein, total lipids, cholesterol and iron in relation to other patients with other indications for liver transplantation $(\mathrm{p}<0.05$, Mann-Whitney U test, data not presented).

Despite several studies citing immunosuppressive medication as a strong predictor for the presence of dyslipidemia, ${ }^{9-10}$ in this study, no association between the use of tacrolimus, cyclosporine or prednisone remained in the final models of the multivariate analysis. However, it is important to note that few patients at the time of assessment $(11 \%, \mathrm{n}=15)$ used cyclosporine as an immunosuppressive drug, which may represent a bias.

\section{Conclusion}

The results of this study suggest that the majority of patients present some type of dyslipidemia afte $r$ transplantation, with the most common types being reduced HDL, followed by hypertriglyceridemia. The predictive factors for the dyslipidemias studied include the existence of at least one potentially modifiable variable related to body composition, food intake or indications of the levels of physical activity. We should remain attentive to the need to institute measures for preventing the development of dyslipidemia after liver transplantation, decreasing cardiovascular risk, and thereby prolonging the survival of these individuals.

\section{Resumo}

Prevalência e fatores associados às dislipidemias pós-transplante hepático.

Objetivo: determinar a prevalência de anormalidades de colesterol total (CT), lipoproteína de baixa densidade (LDL) e alta densidade (HDL) e triglicérides, e identificar fatores preditivos dessas desordens em pacientes submetidos ao transplante hepático (TxH).

Métodos: estudo transversal de avaliação da prevalência de dislipidemias em pacientes submetidos ao TxH. Variáveis demográficas, socioeconômicas, clínicas, antropométricas e dietéticas foram coletadas para identificar os fatores associados utilizando análises estatísticas uni e multivariadas.
Resultados: foram avaliados 136 pacientes, dos quais 68,1\% apresentaram pelo menos um tipo de dislipidemia. O nível de triglicérides esteve elevado em 32,4\% dos casos, a HDL reduzida em 49,3\% dos pacientes e os níveis de LDL elevados em apenas $8,8 \%$. Colesterol total elevado foi observado em $16,2 \%$ da população estudada e esteve associado à indicação de transplante por cirrose etanólica $(\mathrm{OR}=2,7)$ e maior número de horas dormidas por noite $(\mathrm{OR}=1,5)$.

Conclusão: grande parte dos pacientes apresentou dislipidemia após o transplante, demonstrando a necessidade de intervenções em relação aos fatores modificáveis associados às dislipidemias que podem atenuar ou prevenir essas desordens.

Unitermos: dislipidemia; lipoproteínas; prevalência; transplante de fígado.

\section{References}

1. Sposito AC, Caramelli B, Fonseca FAH, Bertolami MC. IV Diretriz Brasileira Sobre Dislipidemias e Prevenção da Aterosclerose Departamento de Aterosclerose da Sociedade Brasileira de Cardiologia. Arq Bras Cardiol. 2007;8(Supl 1):1-19.

2. Gisbert C, Prieto M, Berenguer M, Bretó M, Carrasco D, de Juan M, et al. Hyperlipidemia in liver transplant recipients: prevalence and risk factors. Liver Transpl Surg.1997;3(4):416-22.

3. Bianchi G, Marchesini G, Marzocchi R, Pinna AD, Zoli M. Metabolic syndrome in liver transplantation: relation to etiology and immunosuppression. Liver Transpl. 2008;14(11):1648-54.

4. Guckelberger O, Bechstein WO, Neuhaus R, Luesebrink R, Lemmens HP, et al. Cardiovascular risk factors in long-term follow-up after orthotopic liver transplantation. Clin Transplant. 1997;11(1):60-5

5. Laryea M, Watt KD, Molinari M, Walsh MJ, McAlister VC, Marotta PJ, et al. Metabolic syndrome in liver transplant recipients: prevalence and association with major vascular events. Liver Transpl. 2007;13(8):1109-14.

6. Muñoz LE, Nañez H, Rositas F, Pérez E, Razo S, Cordero P, et al. Long-term complications and survival of patients after orthotopic liver transplantation. Transplant Proc. 2010;42(6):2381-2.

7. Hanouneh IA, Feldstein AE, McCullough AJ, Miller C, Aucejo F, Yerian L, Lopez $\mathrm{R}$, et al. The significance of metabolic syndrome in the setting of recurrent hepatitis C after liver transplantation. Liver Transpl. 2008;14(9):1287-93.

8. Guckelberger O, Mutzke F, Glanemann M, Neumann UP, Jonas S, Neuhaus $\mathrm{R}$, et al. Validation of cardiovascular risk scores in a liver transplant population. Liver Transpl. 2006;12(3):394-401.

9. Manzarbeitia C, Reich DJ, Rothstein KD, Braitman LE, Levin S, Munoz SJ Tacrolimus conversion improves hyperlipidemic states in stable liver transplant recipients. Liver Transpl. 2001;7(2):93-9.

10. Fernandez-Miranda C, Guijarro C, de la Calle A, Loinaz C, Gonzalez-Pinto I, Gómez-Izquierdo T, et al. Lipid abnormalities in stable liver transplant recipients-effects of cyclosporin, tacrolimus, and steroids. Transpl Int. 1998;11(2):137-42

11. Groth CG, Backman L, Morales JM, Calne R, Kreis H, Lang P, et al. Sirolimus (rapamycin)-based therapy in human renal transplantation: similar efficacy and different toxicity compared with cyclosporine. Sirolimus European Renal Transplant Study Group. Transplantation. 1999;67(7):1036-42.

12. Kahn HS, Williamson DF, Stevens JA. Race and weight change in US women: the roles of socioeconomic and marital status. Am J Public Health. 1991;81(3):319-323.

13. Kniepeiss D, Iberer F, Schaffellner S, Jakoby E, Duller D, Tscheliessnigg K. Dyslipidemia during sirolimus therapy in patients after liver transplantation. Clin Transplant. 2004;18(6):642-6.

14. Trotter JF, Wachs ME, Trouillot TE, Bak T, Kugelmas M, Kam I, et al. Dyslipidemia during sirolimus therapy in liver transplant recipients occurs with concomitant cyclosporine but not tacrolimus. Liver Transpl. 2001;7(5):401-8. 
15. Santos RD. [III Brazilian Guidelines on Dyslipidemias and Guideline of Atherosclerosis Prevention from Atherosclerosis Department of Sociedade Brasileira de Cardiologia]. Arq Bras Cardiol. 2001;77 (Supl3):1-48.

16. Ainsworth BE, Haskell WL, Whitt MC, Irwin ML, Swartz AM,Strath SJ, et al. Compendium of physical activities: an update of activity codes and MET intensities. Med Sci Sports Exerc. 2000;32(Suppl 9):498-504.

17. World Health Organization. WHO. Energy and protein requirements. Geneva: WHO; 1985.

18. World Health Organization. WHO. Obesity: preventing and managing the global epidemic. Geneva: WHO; 1998.

19. Alberti KG, Zimmet P, Shaw J. Metabolic syndrome--a new world-wide definition. A Consensus Statement from the International Diabetes Federation. Diabet Med. 2006;23(5):469-80.

20. Phillipi ST. Tabela de composição de alimentos: suporte para decisão nutricional. Brasília (DF): ANVISA, FINATEC/NUT-UnB; 2001.

21. Pinheiro ABVL, Benzecry EH, Gomes MCS, Costa VM. Tabela para avaliação de consumo alimentar em medidas caseiras. São Paulo: Atheneu; 2000

22. Dehghani SM, Taghavi SA, Eshraghian A, Gholami S, Imanieh MH, Bordbar MR, et al. Hyperlipidemia in Iranian liver transplant recipients: prevalence and risk factors. J Gastroenterol. 2007;42(9):769-74.

23. Munoz SJ, Deems RO, Moritz MJ, Martin P, Jarrell BE, Maddrey WC. Hyperlipidemia and obesity after orthotopic liver transplantation. Transplant Proc.1991;23:1480-3.

24. Pagadala M, Zein CO, McCullough AJ. Predictors of steatohepatitis and advanced fibrosis in non-alcoholic fatty liver disease. Clin Liver Dis.2009;13(4):591-606.

25. de Souza LJ, Souto Filho JT, de Souza TF, Reis AF, Gicovate Neto C, et al. Prevalence of dyslipidemia and risk factors in Campos dos Goytacazes, in the Brazilian state of Rio de Janeiro. Arq Bras Cardiol. 2003;81(3):249-64.

26. Lessa I, Conceicao JL, Souza ML, Oliveira V, Carneiro J, Melo J, et al. Prevalence of dyslipidemias in adults in laboratory tests from Salvador, Brazil. Arq Bras Cardiol. 1997;69(6):395-400

27. Bertolami MC, Bertolami A. Epidemiologia das dislipidemias. Rev Soc Cardiol Estado de São Paulo. 2006;16(1):24-30.

28. Malnick SD, Beergabel M, Knobler $\mathrm{H}$. Non-alcoholic fatty liver: a common manifestation of a metabolic disorder. QJM. 2003;96(10):699-709.

29. Ong J, Younossi ZM, Reddy V. Cryptogenic cirrhosis and posttransplantation nonalcoholic fatty liver disease. Liver Transpl. 2001;7(9):797-801.

30. Esmaillzadeh A, Kimiagar M, Mehrabi Y, Azadbakht L, Hu FB, Willett WC. Dietary patterns, insulin resistance, and prevalence of the metabolic syndrome in women. Am J Clin Nutr. 2007;85(3):910-18.
31. Hu FB, Willett WC. Optimal diets for prevention of coronary heart disease. JAMA. 2002;288(20):2569-78.

32. Menke A, Muntner P, Wildman RP, Reynolds K, He J. Measures of adiposity and cardiovascular disease risk factors. Obesity. 2007;15(3):785-95.

33. Montague CT, O'Rahilly S. The perils of portliness: causes and consequences of visceral adiposity. Diabetes. 2000;49(6):883-8.

34. Gagliardi L, Wittert G. Management of obesity in patients with type 2 diabetes mellitus. Curr Diabetes Rev.2007;3(2):95-101.

35. Vanni E, Bugianesi E, Kotronen A, De Minicis S, Yki-Jarvinen H, SvegliatiBaroni G. From the metabolic syndrome to NAFLD or vice versa? Dig Liver Dis.(2010); 42(5):320-30.

36. Eckel RH, Grundy SM, Zimmet PZ. The metabolic syndrome. Lancet. 2005;365(9468):1415-28.

37. Djousse L, Arnett DK, Coon H, Province MA, Moore LL, Ellison RC. Fruit and vegetable consumption and LDL cholesterol: the National Heart, Lung, and Blood Institute Family Heart Study. Am J Clin Nutr. 2004;79(2):213-7.

38. Saab S, Wiese C, Ibrahim AB, Peralta L, Durazo F, Han S, et al. Employment and quality of life in liver transplant recipients. Liver Transpl. 2007;13(9):1330-8.

39. Painter P, Krasnoff J, Paul SM, Ascher NL. Physical activity and healthrelated quality of life in liver transplant recipients. Liver Transpl. 2001;7(3):213-9.

40. Pinho RA, Araujo MC, Ghisi GL, Benetti M. Coronary heart disease, physical exercise and oxidative stress. Arq Bras Cardiol. 94(4):549-55.

41. Bellinghieri G, Bernardi A, Piva M, Pati T, Stoppa F, Scaramuzzo P, et al. Metabolic syndrome after kidney transplantation. J Ren Nutr. 2009;19(1):105-10.

42. Mooradian AD. Dyslipidemia in type 2 diabetes mellitus. Nat Clin Pract Endocrinol Metab. 2009;5(3):150-9.

43. Gangwisch JE, Malaspina D, Babiss LA, Opler MG, Posner K, Shen S, et al. Short sleep duration as a risk factor for hypercholesterolemia: analyses of the National Longitudinal Study of Adolescent Health. Sleep. 2010;33(7):956-61.

44. Alvarez GG, Ayas NT. The impact of daily sleep duration on health: a review of the literature. Prog Cardiovasc Nurs. 2004;19(2):56-9.

45. Chaput JP, Despres JP, Bouchard C, Tremblay A. The association between sleep duration and weight gain in adults: a 6-year prospective study from the Quebec Family Study. Sleep. 2008;31(4):517-23.

46. Gruchow HW, Sobocinski KA, Barboriak JJ, Scheller JG. Alcohol consumption, nutrient intake and relative body weight among US adults. Am J Clin Nutr. 1985;42(2):289-95. 